\title{
EFFECT OF ENVIRONMENTAL AND PARAGENETIC FACTORS ON BIRTH MASS VARIABILITY OF MIS SHEEP POPULATIONS
}

\author{
M. P. Petrović ${ }^{1}$, D. Ružić- Muslić ${ }^{1}$, N. Maksimović ${ }^{1}$, N. Memiši ${ }^{2}$ \\ ${ }^{1}$ Institute for Animal Husbandry, Belgrade-Zemun \\ ${ }^{2}$ AD Mlekara, Subotica \\ Corresponding author: milanppet@yahoo.com \\ Original scientific paper
}

Abstract: The aim of the study was to determine effect of environmental and paragenetic factors on body mass of lambs at birth. Investigation was realised on experimental sheep farm of Institute for Animal Husbandry, Belgrade-Zemun. Animal included in this research were representatives of Mis sheep population. The results of the research confirm that values of the birth mass range from $4.43 \mathrm{~kg}$ to $4,58 \mathrm{~kg}$ observed by years and $4.48 \mathrm{~kg}$ to $4.55 \mathrm{~kg}$ depending on the lambing season. Statistical analysis showed that the existing differences still significant on the level $(\mathrm{P}<0.05)$. Variations of body mass in lambs depending on the mother's age range in the interval from $4.29 \mathrm{~kg}$ to $4.52 \mathrm{~kg} \mathrm{~kg}$ and statistically very significant $(\mathrm{P}<0.01)$. Type of birth has also expressed a significant effect on the body mass of lambs at birth and variations range from $4.31 \mathrm{~kg}$ (twins) to $4.59 \mathrm{~kg}$ (single). Existing differences was statistically very significant $(\mathrm{P}<0.01)$. Average body mass in lambs depending on sex of lamb were almost the same, $4.54 \mathrm{~kg}$ male and $4.52 \mathrm{~kg}$ female, and the difference is not statistically significant $(\mathrm{P}>0.05)$.

Key words: lamb, season, birth mass, environmental and paragenetic factors

\section{Introduction}

Estrus in the majority of sheep in Serbia has a seasonal character, which means that the sheep exhibit sexual glow during the summer from July to September. It is linked to many as genetic and external factors (Petrović, 2000). For example different breeds of sheep express estrus in different time depending on the areas where they are reared (England, Australia, Serbia). With regard to this, lambing in our country mainly during the winter months, which is not always good 
from the aspect of marketing. Therefore, it is in the implementation of so-called off-season lambing in defined period of years. Number of lambs born by lambing is one of the most important indicators of productivity of sheep. For example effect of litter size showed significant effect on milk production in sheep (Petrović et al, 2008) .In other words, the biological efficiency of sheep is caused by fertility. Body weight of lambs at birth has an important role in achieving a good production, because of the initial body mass depends not only growth, but also vitality and mortality of sheep (Morris et al, 2000, Cloete et al, 2001, Zapasnikiene, 2002, Berhan and Arendonk, 2006). Body mass at birth influenced by many factors of genetic and paragenetic nature. Today, among other things, scientists analyzed of genetic biodiversity of some genes related to growth and development of lambs (Ali et al, 2009). A number of researchers reported that body weight of lambs at birth differed significantly due to year and season of birth, age of the dam, birth type and sex of lamb born (Sormunen and Suvela, 1999, Hansen and Shrestha, 2002, Fisher, 2004; Rosa and Bryant, 2003, Babar et al, 2004, Sušić et al, 2005).

\section{Materials and methods}

Investigation was realised on experimental sheep farm of Institute for Animal Husbandry, Belgrade-Zemun. Animal included in this research were representatives of Mis sheep population. The data were analyyed to estimate the effect of year and season of birth of lamb, age of the dam, birth type and sex of lamb. The dams were grouped into three age groups on the basis of their age at lambing: young ( $<4$ years), mature ( 4,1 to 6 years) and old ( $>6.1$ years).

The mathematical analysis was done using the next model of Least Squares and Maximum Likelihood computer program (Harvey, 1991):

Yijklmn $=\mu+\mathrm{Gi}+\mathrm{Sj}+\mathrm{Dk}+\mathrm{Tl}+\mathrm{Pm}+(\mathrm{DT}) \mathrm{kl}+(\mathrm{TP}) \mathrm{lm}+$ eijklmn, where:

Yijklmn = body weight of nth lamb of mth sex lth birth type and kth age of dam and born during jth season in ith year $\mu=$ overall population mean

$\mathrm{Gi}=$ effect of $i$ th year

$\mathrm{Sj}=$ effect of $\mathrm{jth}$ season

$\mathrm{Dk}=$ effect of kth age of the dam

$\mathrm{Tl}=$ effect of lth type of birth

$\mathrm{Pm}=$ effect of sex of lamb born 
(DT)kl = effect of interaction between kth age group and lth birth type

(TP) $1 \mathrm{~m}=$ effect of interaction between lth birth type

and mth sex of the lamb

Eijklmn $=$ undetermined effects

\section{Result and discussion}

Results of influence of the year and season as environmental factors on the body mass of lambs at birth, are shown in Table 1.

Table 1. Effect of environmental factors on weight of lambs at birth

\begin{tabular}{|c|c|c|c|c|}
\hline \multicolumn{2}{|c|}{ Effect } & Number of records & LSM & $\pm \mathrm{SE}$ \\
\hline Year & $\begin{array}{c}1 \\
2 \\
3 \\
4 \\
5 \\
6 \\
7 \\
8 \\
9 \\
10 \\
1-10 \\
\end{array}$ & $\begin{array}{c}54 \\
60 \\
65 \\
70 \\
80 \\
88 \\
95 \\
120 \\
122 \\
130 \\
884 \\
\end{array}$ & $\begin{array}{l}4.46 \\
4.43 \\
4.51 \\
4.48 \\
4.45 \\
4.57 \\
4.47 \\
4.52 \\
4.58 \\
4.56 \\
4.50 \\
\end{array}$ & $\begin{array}{l}0.11 \\
0.09 \\
0.13 \\
0.08 \\
0.06 \\
0.09 \\
0.14 \\
0.15 \\
0.09 \\
0.08 \\
0.10\end{array}$ \\
\hline Season & $\begin{array}{l}\text { Autumn-winter } \\
\text { Spring-summer }\end{array}$ & $\begin{array}{l}653 \\
428\end{array}$ & $\begin{array}{l}4.48 \\
4.55\end{array}$ & $\begin{array}{l}0.13 \\
0.19\end{array}$ \\
\hline
\end{tabular}

Despite the differences in body weight of lambs, we do not see a great variability. The values of the birth mass range from $4.43 \mathrm{~kg}$ to $4,58 \mathrm{~kg}$ observed by years and $4.48 \mathrm{~kg}$ to $4.55 \mathrm{~kg}$ depending on the lambing season. Significance test (table 3) showed that the existing differences still significant, but the level $(\mathrm{P}<0.05)$.

From Table 1. also can see that the lambs was born in the spring-summer season have a heaviest body mass at birth. Since the research was conducted on the same sheep population, the difference can be interpreted only as the factor of food, in other word, it is the effect of pasture grass and natural environment.

Quantity and quality of pasture in the spring-summer season, vary a lot depending on the meteorological conditions, especially the number of rainy and sunny days. Therefore, variations in body weight of lambs at the birth of a common influence of external factors. During the autumn-winter season, when the sheep 
stodgy food and concentrated food in the manger, the amount and quality of food is a decisive influence on the development of external and mass lambs.

Table 2. presents the results of the influence of paragenetic factors on body mass of lambs.

Table 2. Effect of paragenetical factors on weight of lambs at birth

\begin{tabular}{|l|l|c|c|c|}
\hline \multicolumn{2}{|l|}{ Effect } & Number of records & LSM & \pm SE \\
\hline Age of & Young & 302 & 4.29 & 0.11 \\
dam & Mature & 628 & 4.57 & 0.09 \\
& Old & 141 & 4.52 & 0.08 \\
\hline Birth type & Single & 721 & 4.59 & 0.09 \\
& Multiple & 363 & 4.31 & 0.12 \\
\hline Sex of & Male & 521 & 4.54 & 0.15 \\
lamb & Female & 538 & 4.52 & 0.10 \\
\hline
\end{tabular}

We can see that young and old mothers give lighter lambs, while sheep in the middle ages-mature as they top their lambs have heaviest body mass. Variations of body mass in lambs depending on the mother's age range in the interval from 4.29 to $4.52 \mathrm{~kg} \mathrm{~kg}$ and statistically very significant $(\mathrm{P}<0.01)$.

Type of birth has also expressed a significant effect on the body mass of lambs at birth Variations body mass range in the interval from $4.31 \mathrm{~kg}$ (twins) to $4.59 \mathrm{~kg}$ (single). This is in line with the trend noted that the lamb twins easier compared to single. Significance test in table 3 , show that existing differences in the average body weight of lambs was statistically very significant $(\mathrm{P}<0.01)$. Average body mass in lambs depending on sex of lamb were almost the same, $4.54 \mathrm{~kg}$ male and $4.52 \mathrm{~kg}$ female, and the difference is not statistically significant $(\mathrm{P}>0.05)$.

Table 3. Significance test for factors affecting body mass variation of lambs

\begin{tabular}{|l|c|c|}
\hline Source of Variation & Degrees of freedom & $\mathrm{F}$ \\
\hline Year & 9 & $*$ \\
\hline Season & 1 & $* *$ \\
\hline Age of dam & 2 & $* *$ \\
\hline Birth tipe & 1 & n.s \\
\hline Sex of lamb & 1 & $* *$ \\
\hline Age x birth type & 2 & n.s \\
\hline Birth type x sex & 1 & $*$ \\
\hline
\end{tabular}

n.s-P $>0.05 ; *$-P $<0.05 ; * *$-P $<0.01$ 
In Table 3., we can see that effect of interaction age $\mathrm{x}$ birth type which was statistically very significant $(\mathrm{P}<0.01)$, but interaction birth type $\mathrm{x}$ sex was non significant $(\mathrm{P}>0.05)$.

The results of these investigations are similar to those citing other authors. Thus, Babara et al., 2004 states that the birth weight of lambs differed significantly due to year and season of birth, age of the dam, birth type and sex of lambs. Unal and Akcapinar (2001) reported that the effect of birth year, age of dam, sex and type of rearing on birth weight was significant. Birth weight is influenced by breed (genotype), sex of lamb, birth type, age of dam, feeding conditions and production system (Notter et al., 1991, 2005). Lambs born in different seasons of the year tend to have different birth weights. Mendel et al. (1989) stated that Merinolandschaf lambs born in spring (mean birth weight $3.9 \mathrm{~kg}$ ) and summer (mean birth weight $3.9 \mathrm{~kg}$ ) are heavier than those born in autumn (mean birth weight $3.8 \mathrm{~kg}$ ) and winter (mean birth weight $3.7 \mathrm{~kg}$ ).

\title{
Conclusion
}

The results of the research the influence of environmental and paragenetic factors on body mass of lambs at birth in the Miss sheep population, confirm that for the assessment of genotype should know a number of factors non genetic nature. Among them are environmental (year, season), which is reflected primarily through the diet, keeping and care of animals during the production cycle, especially during the pregnancy in observed year and season. In addition to environmental factors, an important influence on the observed feature are age of mothers, type of birth and sex of lamb, i.e. factors that can not be called environmental, but a certain biological category, which is the best call paragenetic or non-genetic influence. All of these factors in greater or lesser extent, as confirmed by this research, affect the body mass of lambs at birth and therefore they should be taken into account in genetic evaluation of the value of Mis sheep.

\section{Uticaj spoljnih i paragenetskih faktora na varijabilnost mase tela jagnjadi mis populacije}

\author{
M. P. Petrović, D. Ružić-Muslić, N. Maksimović, N. Memiši
}

\section{Rezime}

Polni žar kod većine ovaca u Srbiji ima sezonski karakter, što znači da ovce ispoljavaju estrus u toku letnjih meseci od jula do septembra. To je povezano sa mnogim genetskim i spoljnim faktorima počev od klime i trajanja svetlosnog 
dana do ishrane i drugih uticaja na organizam životinje. Najbolja potvrda ovome je da ovce iste rase ispoljavaju polni žar u različito vreme u zavisnosti od geografsoklimatskog područja gde se gaje (naprimer: Engleska, Australija ili Srbija). Sa tim u vezi i jagnjenje ovaca pada u različitim sezonama, a kod nas pretežno tokom zimskih meseci, što nije najbolje sa aspekta plasmana jagnjadi. Zato je u primeni i takozvano vansezonsko jagnjenje, gde se ovce jagnje u različitom i planski definisanom periodu godine. Broj potomaka dobijenih po jagnjenju jedan je od najvažnijih pokazatelja produktivnosti ovaca. Drugim rečima, biološka efikasnost ovaca je uslovljena plodnošću odnosno sposobnošću reprodukcije. Masa jagnjadi pri rođenju ima veliku ulogu u ostvarenju profitabilne proizvodnje, jer od početne mase tela zavise ne samo prirast, već vitalnost i mortalitet jagnjadi. Na masu tela pri rođenju utiču brojni faktori genetske i paragenetske prirode. Ovim problemom su se bavili mnogi istraživači, a ta tema je aktuelna i danas. Rezultati naših istraživanja uticaja spoljnih i paragenetskih faktora na masu tela jagnjadi pri rođenju u populaciji Mis ovce, potvrđuju da za procenu genotipa treba poznavati više faktora negenetske prirode. Među njima su spoljna sredina (godina, sezona) koji se pre svega ogledaju preko ishrane, držanja i nege životinja tokom proizvodnog ciklusa, a posebno u toku bremenitosti. Pored spoljnih faktora, bitan uticaj na posmatranu osobinu imaju: starost majke, tip rođenja i pol jagnjadi, dakle faktori koje ne možemo zvati spoljnom sredinom, već određenom biološkom kategorijom, koju je najprikladnije nazvati paragenetskim uticajem. Svi ovi faktori u većoj ili manjoj meri, kako to potvrđuju ova istraživanja, utiču na masu tela jagnjadi pri rođenju i zato ih treba uzimati u obzir prilikom procene genetske vrednosti ovaca Mis populacije.

\section{References}

ALI B.A, EL-HANAFI A.A, SALEM H.H (2009): Genetic biodiversity studies on IGFBP-3 gene in Egyptian sheep breeds. Biotechnology in Animal Husbandry 25(1-2), 101-109.

BABAR M.E., AHMAD Z., NADEEM A, YAQOOB M. (2004): Environmental factors affecting birth weight in Lohi sheep. Pak.Vet. Jour., 24 (1) 5-9.

BERHAN, A. AND J.VAN ARENDONK. (2006): Reproductive performance and mortality rate in Menz and Horro sheep following controlled breeding in Ethiopia. Small Rumin. Res. 63:297303.

CLOETE S.W.P., GREEFF J.C., LEWER R.P. (2001): Environmental and genetic aspects of survival and early live weight in Western Australian Merino sheep. South African Journal of Animal Science, 31(2) 123-130.

FISHER, M. W. (2004): A review of the welfare implications of out-of-season extensive lamb production systems in New Zealand. Livest. Prod. Sci. 85, 165-173. 
HANSEN, C., J. N. B. SHRESTHA (2002): Consistency of genetic parameters of productivity for ewes lambing in February, June, and October under an 8-month breeding management. Small Rum. Res. 44, 1-8.

HARVEY, W. R.( 1991): Mixed Model Least Squares and Maximum Likelihood Computer Program. The Ohio State Univ. Columbus, OH, USA

MENDEL, C., W. SCHOLAUT, F. PIRCHNER (1989): Performance of Merinolandschaf and Bergschaf under an accelerated lambing system. Livest. Prod. Sci. 21, 131-141.

NOTTER, D. R., R. F. KELLY, F. S. McCLAUGHERTY (1991): Effects of ewe breed and management system on efficiency of lamb production. II. Lamb growth, survival and carcass characteristics. J. Anim. Sci. 69, 22-33.

NOTTER, D.R., R.C. BORG AND L.A. KUEHN. (2005): Adjustment of lamb birth and weaning weights for continuous effects of ewe age. Anim. Sci., 80: 241-248.

MORRIS, C. A., S. M. HICKEY AND J. N. CLARKE. (2000): Genetic and environmental factors affecting lamb survival at birth and through to weaning. NZ. J. Agric. Res. 43:515-524.

NOTTER, D.R., R.C. BORG AND L.A. KUEHN.(2005): Adjustment of lamb birth and weaning weights for continuous effects of ewe age. Anim. Sci., 80: 241-249.

PETROVIC P.M (2000): Genetic and improvement of sheep. Naučna, Belgrade, p. 365.

PETROVIC P.M, RUZIC-MUSLIC D, ZUJOVIC M, CARO-PETROVIC V, PERISIC P (2008): Investigation of genetic and paragenetic parameters of milk production in sheep. Egyptian Journal of Sheep and Goat Sciences. 3(1), 1-6.

ROSA, H. J. D., M. J. BRYANT (2003): Seasonality of reproduction in sheep. Small Rum. Res. 48, 155-171.

SORMUNEN-CHRISTIAN, R., M. SUVELA (1999): Out-of-season lambing of Finnish landrace ewes. Small Rum. Res. 31, 265-272.

SUŠIĆ, V., V. PAVIĆ, B. MIOČ, I. ŠTOKOVIĆ, A. EKERT KABALIN Seasonal variations in lamb birth weight and mortality. Vet. arhiv 75, 375-381, 2005.

UNAL, N. AND H. AKCAPINAR. (2001): Some important production traits of central Anatolian Merino sheep and possibilities of improving through selection of these traits. I. Important production traits. Lalahan-Hayvancilik-ArastirmaEnstitusu-Dergisi. 41(1):45-58.

ZAPASNIKIENE B. (2002): The effect of age of ewes and lambing season on litter size and weight of lambs. Veterinaria in zootechnika. 19 (41) 112-115. 